\title{
THE EFFECT OF REFINERY AND PETROCHEMICAL EFFLUENT ON WATER QUALITY OF UBEJI CREEK WARRI, SOUTHERN NIGERIA.
}

\author{
Uzoekwe, S. A. and Oghosanine, F.A \\ http://dx.doi.org/10.4314/ejesm.v4i2.12
}

\begin{abstract}
This study investigated the effects of treated effluent discharge on the water quality of Ubeji Creek, Warri. Water and sediment samples were collected from upstream and downstream sections of the creek. Physicochemical parameters and concentrations of heavy metals of the receiving water body (upstream and downstream) were compared with that of the treated effluent. Recorded mean $\mathrm{pH}$ values of the effluent, receiving water body and sediment were $6.26 \pm 0.04,6.90 \pm 0.06$ (upstream), $6.87 \pm 0.01$ (downstream) and $6.54 \pm 0.44$ respectively. Electrical conductivity ranged from $1150.41 \pm 0.01-151.50 \pm 0.71 \mu \mathrm{S} / \mathrm{cm}$ for water samples and mean value of $1870.00 \pm 1117.23 \mu \mathrm{S} / \mathrm{cm}$ for sediment. Total hydrocarbon (THC) and total dissolved solids (TDS) varied from maximum values of $8.81 \pm 0.01-2.83 \pm 0.04 \mathrm{mg} / \mathrm{l}$ and $575.15 \pm 0.07-$ $75.72 \pm 0.26 \mathrm{mg} / \mathrm{l}$ respectively. Nitrate and phosphate level was observed to be higher in the sediment (45.30 $\pm 3.96 \mathrm{mg} / \mathrm{l}$ and $9.62 \pm 2.57 \mathrm{mg} / \mathrm{l}$ respectively) than the level obtained for upstream (0.35 \pm 0.01 and $0.01 \pm$ $0.00 \mathrm{mg} / \mathrm{l})$ and downstream $(0.25 \pm 0.03$ and $0.01 \pm 0.00 \mathrm{mg} / \mathrm{l})$. The ranges for exchangeable ions were; $\mathrm{Na}$ $(7.73 \pm 0.24-6.61 \pm 0.24 \mathrm{mg} / \mathrm{ll}), P(5.26 \pm 0.04-2.25 \pm 0.03 \mathrm{mg} / \mathrm{l}), \mathrm{Ca}(34.74 \pm 0.09-13.45 \pm 0.33 \mathrm{mg} / \mathrm{l})$ and $\mathrm{Mg}(2.74 \pm 0.18-1.80 \pm 0.06 \mathrm{mg} / \mathrm{l})$ for water samples; for the sediment, the range is $36.33 \pm 2.50-2.76 \pm$ 0.96 ( $\mathrm{Na}>\mathrm{P}>\mathrm{Ca}>\mathrm{Mg}$ ). The levels of heavy metals (Lead (Pb), Zinc (Zn), Copper (Cu), Iron (Fe), Chromium $(\mathrm{Cr})$, Arsenic (As), Nickel (Ni), Vanadium (V), and Cadmium (Cd)) in water samples and sediment were estimated using Atomic Absorption Spectroscopy. The results obtained, ranges from Fe $(4.29 \pm 0.00-2.76 \pm$ $0.03)$ to $\mathrm{Pb}(0.01 \pm 0.01-0.01 \pm 0.00)$ for water samples and $\mathrm{Zn}(9.40 \pm 1.50)$ to $\mathrm{Cd}(0.05 \pm 0.00)$ for sediment. This value obtained for sediment was observed to be higher than that in the water samples.
\end{abstract}

Keywords: Effluent discharge, water quality, sediment, Heavy metals.

\section{INTRODUCTION}

Nigeria has a vast crude oil and gas deposits and attempts to explore it have left the country with unique vulnerabilities (Nduka and Orisakwe, 2009). Rapid urbanization and industrialization of Warri and its environment between 1968 and 1990 created pollution potential that are as high as some sources of pollution. The rivers, estuaries, creeks and air have been contaminated for decades (Egborge 1995).

Refinery and petrochemical plants generate solid waste and sludge composed of organic, inorganic compounds including heavy metals. Waste water released by petrochemical industries are characterised by the presence of large quantity of polycyclic and aromatic hydrocarbons, phenols, metal derivatives, surface active substances, sulphides, naphthylenic acids and other chemicals (Suleimanov,1995). Due to the ineffectiveness of purification systems, waste water may become dangerous, leading to the

Department of Basic Sciences, Benson Idahosa University, P.M.B. 1100, G.R.A., Ugbor Road, Benin City, Edo State. uzoelwe_steve@yahoo.com accumulation of toxic products in the receiving water bodies with potentially serious consequences on the ecosystem. (Bay et al., 2003). Crude oil is a complex mixture of several polycyclic aromatic compounds and other hydrocarbons. The major hydrocarbon classes found in crude oil are the normal alkanes (rapidly degraded), branched alkanes and cycloalkanes (difficult to identify), the isoprenoids (very resistant to biodegradation), the aromatics (fairly identified and much more soluble than other hydrocarbons), and finally the polar ones containing mainly sulphur, oxygen and/or nitrogen compounds. Non hydrocarbon compounds may also be found in crude oil and they include porphyrins and their derivatives (Callot and Ocampo, 2009).

Delta state forms a large part of the Niger-Delta estuary and the largest oil producing state in Nigeria. Consequently, the state is exposed to a large proportion of the environmental degradation and health hazards associated with exploration and 
exploitation of crude oil. The frequency of oil spill and untreated waste water discharge into water bodies and the attendant negative impact on the aquatic and terrestrial ecosystem is well known and well documented over the years (Nduka and Orisakwe, 2009).

Presence of pollutants in natural waters alters the quality and often pose serious threats to aquatic life. Various studies have shown positive correlation between pollutions from petrochemical and refinery effluents and the health of aquatic organisms (Otukunefor and Obiukwu, 2005). Previous observations suggested a correlation between contaminants of water and sediments with aromatic hydrocarbons from refinery effluents and compromised fish health (Kuehn et al., 1995).

Though petroleum has played an important role in the economy of the country, over the past three decades, Niger delta ecosystem has been subjected to destruction by petroleum product spillage and other effluents resulting from operational activities (Adeniyi and Afolabi, 2002) with increase in processed petroleum products (effluents) that are discharged with little regard to aquatic environment. The contents of the effluents have serious toxicological effects on aquatic environment and humans. Refinery effluent containing oil when discharged into water body can cause depletion of dissolved oxygen due to transformation of organic component into inorganic compounds, loss of biodiversity through a decrease in amphipod population that is important in food chain and eutrophication. Short term toxicity in fishes includes lymphocytosis, epidermal hyperplasia, hemorrhagic septicaemia (Beeby, 1993).

In Nigeria, data on ecological risk assessment of effluent discharge in aquatic environment especially environmentally stressed Niger Delta region is scanty. There is paucity of data on the effect of refinery effluent on various water bodies. However, the quality of refinery effluent and it impact on physico-chemical quality of Okrika arm of the Bonny River estuary has been given (Otokunefor and Obiukuwu, 2005). According toOrisakwe and Nduka (2009), physico-chemical parameters of portable water of contiguous host communities' shows serious pollution burden from effect of refinery effluent. Recently, study of Ubeji creek revealed that fish and aquatic life were absent at the site of effluent discharge and at each site downstream to Ubeji River (Achudume, 2009). Present development suggests that Warri refinery and petrochemical company (WRPC) has taken the issue of effluent treatment more seriously. As part of sustainable regulatory measure, the aim of this study is to determine the effect of effluent discharge on water quality of Warri creek by identifying and evaluating the levels of major contamination it receives.

\section{Materials and Methods}

Description of study area

The study area, Ubeji, is located in Warri, Delta State, Nigeria, at a surface location of $366,140.12 \mathrm{~m}$ Easting and 174,200.08 m Northing. The Ubeji Community is situated beside the Warri Refinery and Petrochemical Company (WRPC). The landforms consist essentially of sedimentary basins and basement complex rocks (Ija and Antai, 2003). The implication of these rocks formations allows permeability of fluids (Achudume, 2009). All industrial wastes, untreated or minimally treated are discharged into Ubeji Creek which runs immediately downstream and eventually ends up in Ubeji River which through Crawford Creek flows into Warri River. The occupation of the human population is mainly fishing and they depend on the creek as an outlet to the larger water. The average atmospheric temperature is $25.5^{\circ} \mathrm{C}$ in the rainy season and $30.10^{\circ} \mathrm{C}$ in the dry season. The daily relative humidity values ranged from $55.5 \%$ in the dry season to $96 \%$ in the rainy season. The Ubeji creek, receives effluent directly from the refinery and petrochemical company.

\section{Sample collection}

Samples were collected $100 \mathrm{~m}$ upstream and $100 \mathrm{~m}$ downstream from the point of effluent discharge in the months of November to December 2010 and January to March 2011. Replicate water samples (upstream and downstream) were collected with a 2 litre plastic hydrobios water sampler and transferred to clean 2 litre polyethylene containers. 


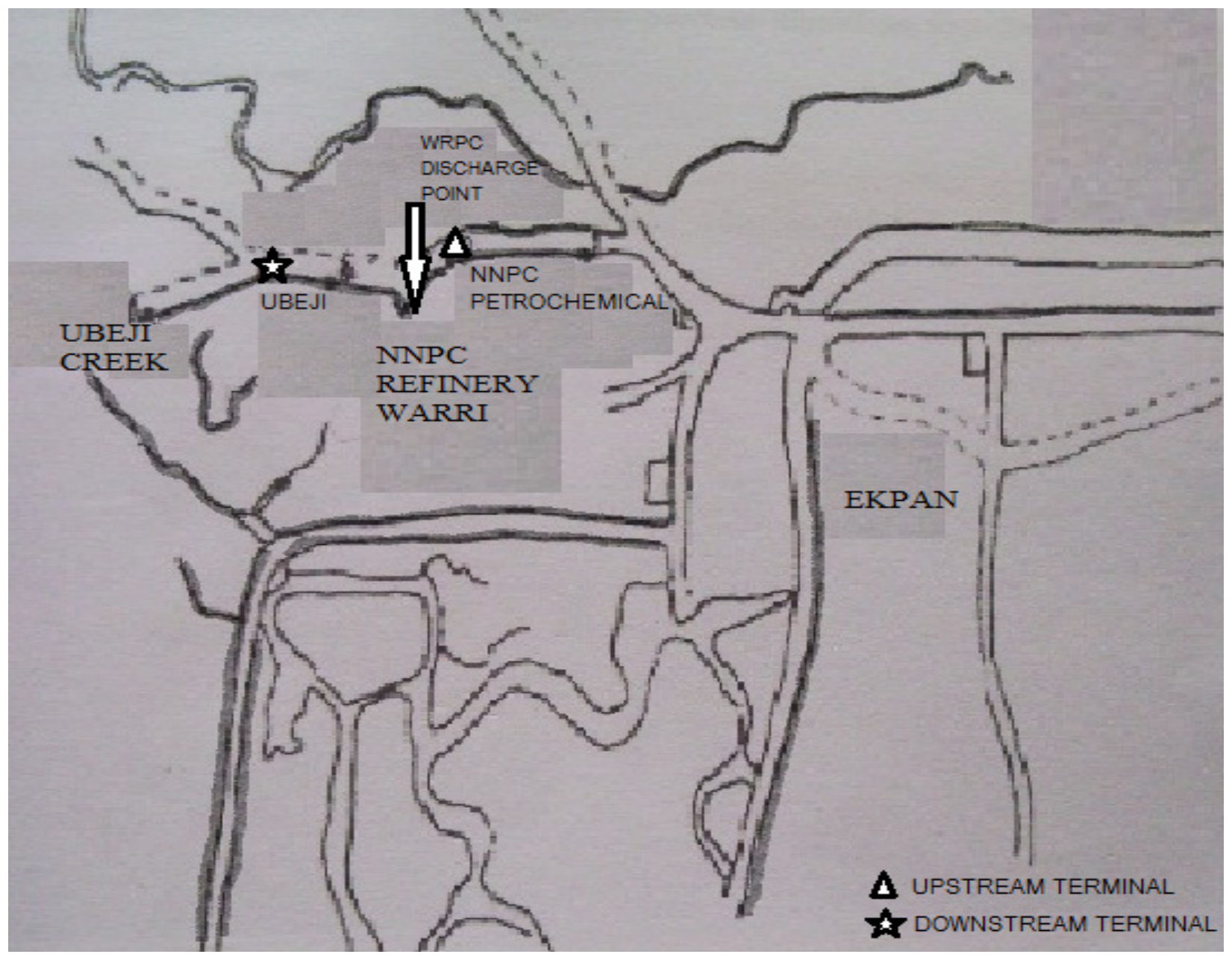

Sample of industrial effluent that had undergone both chemical and biological treatments were collected for comparison. Sediment samples were collected with benthic sampler from various sampling locations (point of effluent discharge, $100 \mathrm{~m}$ upstream and $100 \mathrm{~m}$ downstream) and bulked together to form a composite sample. The sample was put in a polyethylene bag. All samples were taken to the laboratory in ice chest for analyses. Water Analysis

Conductivity, turbidity, TSS, TDS and $\mathrm{pH}$ were measured using $\mathrm{HACH}$ water analysis kits (Model DR 2010). A GBC model 908AA spectrophotometer was used for the determination of dissolved oxygen, biochemical oxygen demand, nitrate, ammonia, sulphate and phosphate. An $\mathrm{HACH}$ COD reactor was used for chemical oxygen demand determination. All analyses were carried out following the procedures outlined in APHA (1995). A Perkin Elmer 3100 atomic absorption spectrophotometer was used for the determination of heavy metals including nickel $(\mathrm{Ni})$, lead $(\mathrm{Pb})$, zinc $(\mathrm{Zn})$, and iron $(\mathrm{Fe})$, copper $(\mathrm{Cu})$, chromium $(\mathrm{Cr})$, arsenic $(\mathrm{As})$, vanadium $(\mathrm{V})$ and cadmium $(\mathrm{Cd})$.

\section{Sediment Analysis}

Sediment sample was air dried by thinly spreading on a clean laboratory bench surface at room temperature and brought to a relatively homogenous state by thoroughly mixing, and sieving with $2 \mathrm{~mm}$ mesh before being treated. The $\mathrm{pH}$ and the conductivity of the sediment were determined by Hach $\mathrm{pH}$ conductivity meter. Total organic carbon was determined by the rapid wet oxidation method based on Walkley and Black (1934). Nutritive salts $\left(\mathrm{NO}_{3}{ }^{-}\right.$, $\left.\mathrm{PO}_{4}{ }^{3-} \mathrm{SO}^{2-}\right)$ and exchangeable cations were determined by method outlined in APHA (1995). The heavy metals content was determined using Perkin Elmer 3100 atomic spectrophotometer. 


\section{Results and Discussion}

The mean \pm standard deviations of physicochemical parameters of the water samples are presented in table 1 . The $\mathrm{pH}$ mean value of the upstream was 6.90 and the downstream 6.87 while that of the treated effluent is 6.26. There was no significant difference between the treated effluent and both upstream the downstream sections $(\mathrm{p}<0.05)$ and all within Federal Ministry of Environment Nigeria (FMEnv.) permissible limit of $6.5-8.5$. The result compares with the findings of Ogunlaja and Ogunlaja (2007) and Nduka and Orisakwe (2009). The authors found that the $\mathrm{pH}$ of the surface water in the same environment and ranged between 6.5 8.5 and are within recommended limits both nationally and internationally. The temperature at the time of study ranged from $25.25^{\circ} \mathrm{C}$ for treated effluent to $23.15{ }^{\circ} \mathrm{C}$ for both upstream and downstream of Ubeji Creek. The observed higher mean temperature at the point of discharge might be due to fresh effluent from refinery plants, and these values pose no threat to the homeostatic balance of the receiving wateand were in agreement with the report of Jaji et al., (2007).

Higher values of total suspended solids (TSS) and turbidity were measured at the discharge point $(10.60 \mathrm{mg} / \mathrm{l}$ and $50.17 \mathrm{NTU})$ and lower values of $(4.58 \mathrm{mg} / \mathrm{l}$ and $21.65 \mathrm{NTU}), \quad(4.58 \mathrm{mg} / \mathrm{l}$ and 21.67NTU) were obtained for upstream and downstream respectively. There were significant difference in values obtained at the discharge point and at upstream and downstream $(\mathrm{P}<0.05)$ for both TSS and turbidity. The turbidity values obtained for all the locations were higher than WHO standards of 5NTU (WHO, 2004). Excessive turbidity in water can cause problem for water purification processes such as flocculation and filtration which may increase treatment cost. High turbid waters are associated with microbial contamination (DWAF, 1988) . Again, turbidity causes decrease in photosynthesis process since turbidity precludes deep penetration of light in water (Muoghalu and Omocho, 2000). Ultimately, the water receiving body is disqualified as source of water for domestic use in the community.
Total Dissolve Solids (TDS) measured at the discharge point was $575.15 \mathrm{mg} / \mathrm{l}$ and the values at the upstream and downstream were $75.75 \mathrm{mg} / \mathrm{l}$ and downstream $75.72 \mathrm{mg} / \mathrm{l}$ respectively, showing a corresponding reduction of about $13.2 \%$ and $13.1 \%$. This reduction may be due to several physiochemical reactions such as sedimentation, coagulation, fixation, amongst other factors like oxidation and precipitation (Wasserman et al 2006). There was significant difference for both upstream and downstream $(\mathrm{P}>0.05)$ but within the FMEnv. limit.

The highest mean value of total hydrocarbon (THC) obtained at the point of discharge $(8.81 \mathrm{mg} / \mathrm{l})$ indicates pollution traceable to oil and gas, and the lower mean value at the upstream $(2.83 \mathrm{mg} / \mathrm{l})$ and that of the downstream $(2.85 \mathrm{mg} / \mathrm{l})$ may be due to seasonal effects as well as surface runoffs and flooding (Fatoki et al., 2001). The results show significant difference between the point of discharge and upstream $(\mathrm{P}<0.05)$ and that of the downstream $(\mathrm{P}<0.05)$. However, result obtained reveal that effluent treatment plant is efficient at least with regards to total hydrocarbon content (THC) treatment. — The electrical conductivity at the point of discharge was $1150.41 \mu \mathrm{S} / \mathrm{cm}$. This decreased markedly to $151.50 \mu \mathrm{S} / \mathrm{cm}$ for downstream and upstream respectively. This correlates with higher values of exchangeable ions estimated in effluent discharge sample. Dissolved ions are responsible for electrical conductivity. However, the values measured for receiving water body were within the set limits.

The dissolved oxygen (DO) concentration of treated effluent $(4.18 \mathrm{mg} / \mathrm{l})$ was observed to lower than DO of the receiving water body (upstream $5.93 \mathrm{mg} / \mathrm{l}$ and downstream $5.98 \mathrm{mg} / \mathrm{l}$ ). The lower value in treated effluent could be attributed to the presence of degradable organic matter. Decrease in DO concentration could be attributable to breakdown of organic matter by aerobic microbes. The oxygen required for this process is taken from the surrounding water thus diminishing its total oxygen content. Odukuma and Okpokwasili (1993) reported that it may be partly due to the displacement of dissolved oxygen by dissolved solids within the effluent. 
Biological Oxygen Demand (BOD) test is useful in determining the relative waste loading and higher degree therefore indicates the presence of large amount of organic pollutant and relatively higher level of microbial activities with consequent depletion of oxygen content. The value measured in the treated effluent was $16.225 \mathrm{mg} / \mathrm{l}$ and this was higher than $8.19 \mathrm{mg} / \mathrm{l}$ and $6.44 \mathrm{mg} / \mathrm{l}$. Similarly the Chemical Oxygen Demand (COD) which is the amount of oxygen used up from a water sample by organic and inorganic chemicals as they break down is far higher in sample collected from discharge point $(58.43 \mathrm{mg} / \mathrm{l})$ than that of water receiving body $(\mathrm{P}<0.05)$.

Some of the impacts of excess salinization on water sources include reduced crop yield, increase in formation of scale of added corrosion and increased requirements for pre treatment of water for selected industrial use such as boiler feed water. There is no significant difference $(p<0.05)$ between the salinity of the receiving water body for both upstream $(45.26 \mathrm{mg} / \mathrm{l})$ and downstream $(46.33 \mathrm{mg} / \mathrm{l})$ and that of treated discharge $(46.72 \mathrm{mg} / \mathrm{l})$; these values are within the DPR and FMENV standards.

With regards to total hardness, no distinctly defined levels of what constitute a hard or soft water supply. The generally accepted classification for hardness of water is $75-150 \mathrm{mg} / \mathrm{L}$ of $\mathrm{CaCO}_{3}$ for soft and $150 \mathrm{mg} / \mathrm{L}$ and above for hard water (Deat, 2000). There was significant difference $(\mathrm{P}<0.05)$ between the point of discharge $(103.4 \mathrm{mg} / \mathrm{l})$ and value measured for upstream and downstream samples. Muoghalu and Omocho (2000) observed that when waste are heavily laden with pollutant and dissolved solids gain access to water bodies, they need large dose of oxygen for decomposition. The mean value of nutrients (total nitrogen, total phosphate, nitrate, sulphate, bicarbonate, orthophosphate and ammonium) differs significantly between bodies. Unpolluted water usually contain only minute amount of nitrate (Jaji et al., 2007). Nitrate a very important nutrient was observed to be within limits with Refinery discharge been $0.87 \mathrm{mg} / \mathrm{l}$, upstream $(0.35 \mathrm{mg} / \mathrm{l})$ and downstream $(0.25 \mathrm{mg} / \mathrm{l})$. Elevated levels in nitrate have been reported to exhibit delayed reactions to light and sound stimuli (Robillard et al., 2003)14 and can cause methaemogloobinemia (Fatoki, 2003). Phosphate was also found to be low. However, nutrient and phosphate are essential nutrients to plants life,but when found in excess quantities, stimulates excessive plant growth such as algae bloom(Igbinosu and Oko, 2009).

The exchangeable ions concentrations of water samples are shown in table 2. Exchangeable ion concentration at the point of discharge ranges from $34.74 \mathrm{mg} / \mathrm{l}$ for calcium to $2.74 \mathrm{mg} / \mathrm{l}$ for magnesium. Higher level of sodium and potassium was also measured $(7.73 \mathrm{mg} / \mathrm{l}$ and $5.26 \mathrm{mg} / \mathrm{l}$ respectively). These values were lower in the upstream and downstream, $13.69 \mathrm{mg} / \mathrm{l}$ (upstream) and $13.45 \mathrm{mg} / \mathrm{l}$ (downstream) for calcium, with significant difference $(\mathrm{P}>0.05), \quad 6.68 \mathrm{mg} / \mathrm{l} \quad$ (upstream) and $6.61 \mathrm{mg} / \mathrm{l}$ (downstream) for sodium with no significant difference $(\mathrm{P}<0.05), \quad 2.25 \mathrm{mg} / \mathrm{l} \quad$ (upstream) and $2.61 \mathrm{mg} / \mathrm{l}$ (downstream) for potassium and $1.80 \mathrm{mg} / \mathrm{l}$ (upstream) and $1.88 \mathrm{mg} / \mathrm{l}$ (downstream) for magnesium with a significant difference $(\mathrm{P}>0.05)$. This suggests strongly that effluent is the source of cation. Sodium increase is as a result of oil leakage (Callot and Ocampo, 2000) ${ }^{7}$. However higher levels were observed in calcium and sodium $(\mathrm{Ca}>\mathrm{Na}>\mathrm{P}>$ $\mathrm{Mg}$ ).

Heavy metal concentrations in water samples are presented in table 3 . Heavy metal concentration in water samples measured in ppm ranges from Nil to $4.29 \mathrm{ppm}$. Generally, higher level of iron, copper, zinc and chromium were determined $(\mathrm{Fe}>\mathrm{Cu}>\mathrm{Zn}>\mathrm{Cr}>$ $\mathrm{Ni}>\mathrm{Pb} \geq \mathrm{As}>\mathrm{V} \geq \mathrm{Cd}$ ). The levels measured were within the Federal Ministry of Environment (FMEnv.) limit. Nickel was Nil (0.00ppm) at the point of discharge but was observed at a higher concentration at the upstream $(0.03 \mathrm{ppm})$ and downstream $(0.03 \mathrm{ppm})$, This higher concentration found in the receiving water body could be traceable to other sources such as waste dump (Adeniyi and Okediyi, 2004). 
The results of physiochemical properties, exchangeable ion and metals of sediment sample are presented in fig 1 . Generally, higher values were measured for the sediments than the water samples. The value obtained for $\mathrm{pH}$ agrees with that of Swingle, (2000) who reported that organic waste reduces the $\mathrm{pH}$ of water and sediment to acidic level. The temperature found in the sediment $\left(27.5^{\circ} \mathrm{C}\right)$ was within set down standards and therefore suitable for aquatic environment. Nitrates and phosphate level in the sediment $(45.30 \mathrm{mg} / \mathrm{kg}$ and $9.62 \mathrm{mg} / \mathrm{kg}$ ), although within the limit of FMEnv was observed to be higher than that found in effluent discharge sample $(0.87 \mathrm{mg} / \mathrm{l}$ for nitrate and $0.01 \mathrm{mg} / \mathrm{l}$ for phosphate) Therefore there is significant difference between the effluent discharge for nitrate $(\mathrm{p}<0.05)$ and that of phosphate $(\mathrm{P}<0.05)$. It is obvious that this high level of nitrate and phosphate in the sediment does not emanate from effluent discharge but probably as a result poor sanitations and leaches from nearby pit latrines (Malomo et al., 2000) and other industrial waste. Crude oil pollution has also been associated with increase in nutritive salts $\left(\mathrm{CO}_{3}{ }^{2-}, \mathrm{SO}_{4}{ }^{2-}, \mathrm{NH}_{4}{ }^{+}\right.$ and $\mathrm{NO}_{5}$ ) and salinity levels of aquatic ecosystem (Rhykered et al., 1995 and Ward et al., 1980). Again results obtained for some of the exchangeable ions were observed to be higher in the sediment than the value obtained for the effluent discharge. Exchangeable ion concentration ranges from $36.33 \mathrm{mg} / \mathrm{kg}$ for sodium to $2.76 \mathrm{mg} / \mathrm{kg}$ for magnesium $(\mathrm{Na}>\mathrm{P}>\mathrm{Ca}>\mathrm{Mg})$.

Mean values of heavy metals determined were found to range from $9.40 \mathrm{ppm}$ for $\operatorname{Zinc}(\mathrm{Zn})$ to nil in Cadmium(Cd) $(\mathrm{Zn}>\mathrm{Fe}>\mathrm{Pb}>\mathrm{Cu}>\mathrm{As}>\mathrm{Ni}>\mathrm{Cr}>$ $\mathrm{V} \geq \mathrm{Cd}$ ). Lead exposure has been associated with hypochromic anaemia with basophilic stifling of erythrocytes (Emory et al., 2001). Cadmium is highly toxic and accumulates in the body and eventually cause effects such as disturbances in calcium homeostasis and metabolism (Emory et al., 2001). Most chromium compounds are carcinogenic, long exposure may cause kidney, liver and nerve damage (Aremu et al., 2000). Generally low level of metal in sediment can be due to washing of soil into surface water by flood and infiltration into underground water. High level of metals may also be attributed to other relevant occupational fields (steel making, welding, cutting, glass and ceramic production etc) (Vilia-Elena, 2006).

\section{Conclusion}

This study revealed that there have been an improvement in the treatment of Warri Refinery and Petrochemical effluent before it is been discharge compared to the studies conducted in the recent past (Achudume, 2009; Nduka and Orisakwe, 2009; Ogunlaja and Ogunlaja, 2009). Efforts made to collect untreated effluent sample from the plant were unsuccessful, though it was found that some of the physicochemical parameters of effluent discharged into this creek is within the limit set by Federal Ministry of Environment Nigeria (FMEnv) while some of the parameters determined for the receiving water body renders Ubeji Creek water unsuitable for domestic use. This suggests other sources of pollution beside refinery effluents may be responsible for elevated levels of some physicochemical parameters in the studied area. The study also indicates the need for continuous monitoring of surface water especially in rural community with high industrial activities.

\section{Acknowledgment}

The authors are indeed very grateful to Dr. Kelvin Idehen and entire staff of Research Laboratory of Petroleum Research Institute of Nigeria (PTI) Effurum, Warri,Delta State, Nigeria for their assistance in samples collection and analyses of some parameters.

\section{References}

Achudume, A. C. (2009). The Effect of Petrochemical Effluent on the Water Quality of Ubeji Creek in Niger Delta Region.Bull Environ.Toxicol., 83: 410 - 415 .

Adeniyi, A. and Afolabi, J. (2002). Determination of total petroleum hydrocarbons and heavy metals in soils within the vicinity of facilities handling refined petroleum. Environ. Int. 28: $79-82$

Adeniyi, A. and Okedeyi, O. (2004). Assessing the speciation pattern of lead and zinc in surface water collected from Abegede creek ijora, Lagos. Park. J. Sci. Indus Res. 47: 430 - 441

American Publicate Health Association (APHA) (1995). Standard Methods for the Examination of Water and Wastewater, $19^{\text {th }}$ edition. APHA/AWWA/WPCF, New York, 5:24-26

Aremu, D., Olawuyi, F., Metshitsuka, S. and Sridhar, K. (2002). Heavy metal analysis of 
groundwater from Warri. Nigeria. Int. J. Environ. Health Res. 12: $61-72$.

Bay, S., Jones, B.H., Schiff, K and Washburn, L. (2003). Marine Environmental Research, 56:205-223.

Beeby,A.(1993). Measuring the effect of Pollution In:Applying Ecology.Chapman and Hall, London, New York.

Callot, H. and Ocampo, R. (2000). Wetlands and Water Pollution. Boston coll. Environ. Aff. Law.Rev. 23: 885 919

Deat, A. (2000). White paper on integrated pollution and waste management for South Africa. A policy on pollution prevention, waste minimization, impact management and remediation. Department of Environmental Affairs and Tourism. 80: 274 -275

DWAF, (1998). Quality of Domestic Water Supplies Assessment Guide 1 ( $\left.2^{\text {nd }} E d n\right)$, Department of Water Affairs and Forestry, Department of Health and Water Research Commision

Egborge, A.B.M. (2001). Water quality index application and industrialization and heavy metal pollution in the warri river, Nigeria. Environ. Pollut. 12: 27 - 40

Egborge, A.B.M.(1995).Water Pollution in Nigeria. Biodiversity and Chemistry of Warri River.Ben Miller Books. Nig.ltd Warri.

Emory, E., Pattole, R., Archiobold, E., Bayorn, M. and Sung, F. (2001). Neurobehavioral effects of low level exposure in human. Neonates. Am. J. Obstet. Gynecol. 181: $5-11$

Fatoki, S., Muyima, N. and lujiza, N. (2001). Suitation analysis of water quality in the Umtata river catchment. Water SA. 27: 67 - 74.

Fatoki, S.O.P. and Ogumfowokan, A.O. (2008). Pollution assessment in the Keiskamma River and in the impoundment downstream. Water SA 29(3): 183 - 187.

Igbinosa,E.O and Oko, A.I.(2009). Impact of discharge wastewater effluents on the physiscochemical qualities of a receiving watershed in a typical rural community. Int. J.Environ.Sci. Tech.6(2):175-182.

Ija, U.J. and Antai S.P. (2003).Removal of Nigeria Light Crude Oil in Soil over 12 months period. Int. Biodegradation, 51:93-99.

Itah, Y. and Essien, G. (2005). Growth Profile and Hydrocarbonoclastic Potential of Microorganisms Isolated from Tarballs in the Bight of Bonny, Nigeria. World Journal of Microbiology and Biotechnology. 21: 6-7.
Jaji, M., Bamgbose, O., Arowolo, T. and Odukoya, O. (2007). Water quality assessment of Ogun River, south west Nigeria. Environ. Monit. Assess. 133: 447 - 482.

Kuehn,R.L.,Berlin,K.D.,Hawkins,W.E.and Ostrander, G.K.(1995). Relationships among petroleum refinery, water and sediments contamination and fish health, Journ. Of Toxic. \& Environ. Health, 46:101-116.

Malomo, S., Okufarasin, V., and Olorunmwo, M. (2000). Ground water chemistry of weathered zone aquifers of an area underlam by basement complex rocks. J. Afr. Earth. Sci. 11: 57- 71.

Muoghalu, L.N. And Omocho V. (2000) Environmantal Health Hazards Resulting from Awka Abattoir. African Journal Environ. Stud. 2:72-73.

Nduka J.K and Orisakwe E.O. (2009). Effect of Effluents from Warri Refinery \& Petrochemical Company (WPRC) on water and soil qualities of "Contigious Host" and impact on communities of Delta State, Nigeria, The Open Environ.Pollut.Toxico. Journ.(1):11-17.

Nduka, k., and Orisakwe, E. (2007). Heavy metals levels and physiochemical quality of portable water supply in warri Nigeria. Annalt. Di. Chem. 97: 86 - 87. Odukuma, L.O. and Okpokwasili. G.C. (1993). Seasonal Influence on Inorganic Anion Monitoring of New Calabar River, Nigeria. Environ. Manage, 17 (4): 491-496.

Ogunlaja,A. and Ogunlaja, O.O.(2007). Physicochemical analysis of water sources in Ubeji Communities and their Histological impact on organs of albino mice. J.Appl.Sci. Environ. Manag., 11(4):91-94.

Otokunefor,T.V. and Obiukwu, C.(2005). Impact of Rifinery Efflluent on physiscochemical Properties of a water body in Niger Delta. Applied Ecology\& Environ. Research,3(1):61-72.

Rao, P. (2005). Textbook of environmental engineering eastern economy, practice of hall of India private limited, New Delhi, chapter 3. Page 280

Revision of the WHO guidelines for drinking water quality. Draft for review and comments. Nitrites and Nitrates in drinking water. World Health Organization (WHO/SCE/WSH/04-081-56).

Rhykered, R.I., Weaver, R.W. And MCLNNES, k.j. (1995). Influence of Salinity on Bioremediation of Oil in Soil. Environ. Pollut., 90, 127-130. 
Robillard P.D., Sharpe W.E. And Wistock, B.R. (2003). Nitrates in Drinking Water. Pennsylvania State University. Agric Biology Eng.

Suleimanov, R.A.(1995). Medicsina Trudai PromyShl ennaia Ekologiia, 12:31-36.

Swingle, H. (2000). Standardization of chemical analysis for waters and pond meals F.A.O. Fish Rep. 44: $394-421$.

Vilia- Elena, S. (2006). Parkinson's disease and exposure to manganese during welding. Tech D.Welding Allied Process. 2: $106-111$

Walkley,A. and Black, I.A.(1934). An examination of the Dagtjareft method for determining soil organic matter and a proposed modification of chromic acid titration method. Soil Science 37:29-38.

Ward, D.M., Atlas, R.M., Boehm, P.D. And Calder, J.A. (1980). Microbial Biodegradation and The Chemical Evolution of Amoco Cadiz Oil Pollutants, Ambio, 9, 277-283.

Wasserman, A., liu, X., and Parvex, F. (2006). Water manganese exposure and children intellectual function in ararhazar bangle desh environ health prospect. Annalt. Di. Chem. 114: 24 - 29.

World Health Organization(WHO) (2004). ROLLING

Table 1: The mean values \pm standard deviation) of physico- chemical properties of effluent discharge and that of receiving river ( upstream and downstream).

\begin{tabular}{|c|c|c|c|c|c|}
\hline Parameters & $\begin{array}{l}\text { Effluent } \\
\text { Discharge }\end{array}$ & Upstream & Downstream & $\begin{array}{l}\text { P- } \\
\text { VALUE }\end{array}$ & $\begin{array}{l}\text { FMEnv Limit } \\
\text { (formerly } \\
\text { FEPA) }\end{array}$ \\
\hline$\overline{\mathrm{pH}}$ & $6.2 \pm 0.04$ & $6.9 \pm 0.06$ & $6.87 \pm 0.01$ & $\mathrm{P}<0.05$ & $6-9$ \\
\hline Temp. ${ }^{\circ} \mathrm{C}$ & $25.26 \pm 0.06$ & $23.15 \pm 0.07$ & $23.15 \pm 0.07$ & $p>0.05$ & 30 \\
\hline $\mathrm{TSS}(\mathrm{mg} / \mathrm{l})$ & $10.25,10.95$ & $4.20,4.95$ & $4.25,4.84$ & & 30 \\
\hline TDS(mg/l) & $575.20,575.10$ & $75.50,76.00$ & $75.53,75.90$ & & 2000 \\
\hline Cond. $(\mu \mathrm{S} / \mathrm{cm})$ & 1150.41 .0 .01 & 151.000 .71 & $151.06,151.80$ & & \\
\hline $\begin{array}{l}\text { Turbidity } \\
(\mathrm{N} / \mathrm{m})\end{array}$ & $50.10,50.23$ & $21.50,21.80$ & $21.69,21.64$ & & \\
\hline DO (mg/l) & $4.17,4.19$ & $5.95,5.90$ & $5.90,5.6 .05$ & & 20 \\
\hline BODs (mg/l) & $16.22,16.30$ & $8.15,8.22$ & $6.43,6.45$ & & 10 \\
\hline CODs(mg/l) & $58.73,58.10$ & $12.85,12.10$ & $11.78,11.38$ & & 30 \\
\hline TOC (mg/l) & $6.26 \pm 0.00$ & $1.34 \pm 0.16$ & $1.39 \pm 0.23$ & $\mathrm{p}>0.05$ & NA \\
\hline $\mathrm{THC}(\mathrm{mg} / \mathrm{l})$ & 8.81 & $2.83 \pm 0.04$ & $2.85 \pm 0.04$ & $\mathrm{p}>0.05$ & 10 \\
\hline Salinity (mg/l) & $47.43,40.00$ & $45.32,45.19$ & $47.43,45.23$ & & \\
\hline Phenol (mg/l) & $0.01 \pm 0.00$ & $0.01 \pm 0.00$ & $0.01 \pm 0.00$ & $\mathrm{P}<0.05$ & \\
\hline Cyanide (mg/l) & $0.01 \pm 0.00$ & $0.01 \pm 0.00$ & $0.01 \pm 0.00$ & $\mathrm{P}<0.050$ & \\
\hline $\mathrm{NH}_{4}^{+}(\mathrm{mg} / \mathrm{L})$ & $1.83 \pm 0.01$ & $0.96 \pm 0.00$ & $0.84 \pm 0.05$ & $\mathrm{p}>0.05$ & \\
\hline $\mathrm{NO}_{3}^{-}(\mathrm{mg} / \mathrm{L})$ & $42.5,48.1$ & $0.35,0.34$ & $0.23,0.27$ & & 20 \\
\hline $\mathrm{SO}^{2-}(\mathrm{mg} / \mathrm{L})$ & $18.38,18.45$ & $8.34,8.76$ & $6.34,6.52$ & & 50 \\
\hline $\mathrm{HCO}_{3}^{-}$ & $18.39,18.34$ & $1.22,1.34$ & $1.12,1.45$ & & 50 \\
\hline $\mathrm{PO}_{4}^{3-}$ & $<0.01$ & $<0.01$ & $<0.01$ & & 5.0 \\
\hline Total Hardness & $103.38,103.41$ & & $37.67,52.96$ & & NA \\
\hline
\end{tabular}

$\mathrm{P}>0.05=$ Significant difference $; \mathrm{P}<0.05=$ No Significant difference FMEnv $=$ Federal Ministry of Environment; FEPA = Federal Environmental Protection Agency Guideline on Effluent Discharge $1991 ;$ N/A $=$ Not Available; THC $=$ Total Hydrocarbon Content:TOC = Total Organic Carbon. 
Table 2: Exchangeable ion Concentration in Water Samples (mean \pm deviation)

\begin{tabular}{|l|l|l|l|l|l|l|l|l|}
\hline Parameters & $\begin{array}{l}\text { Effluent } \\
\text { Discharge }\end{array}$ & Upstream & P-VALUE & $\begin{array}{l}\text { Effluent } \\
\text { Discharge }\end{array}$ & Downstream & $\mathrm{p}$ - value & DPR & FMENV \\
\hline Sodium mg/l & $7.73 \pm 0.24$ & $6.68 \pm 0.34$ & $\mathrm{P}<0.05$ & $7.73 \pm 0.24$ & $6.61 \pm 0.24$ & $\mathrm{p}>0.05$ & N/A & N/A \\
\hline Potassium mg/l & $5.26 \pm 0.04$ & $2.25 \pm 0.03$ & $\mathrm{p}>0.05$ & $5.26 \pm 0.04$ & $2.61 \pm 0.23$ & $\mathrm{p}>0.05$ & N/A & N/A \\
\hline Calcium mg/l & $34.74 \pm 0.09$ & $13.69 \pm 0.33$ & $\mathrm{p}>0.05$ & $34.74 \pm 0.09$ & $13.45 \pm 0.33$ & $\mathrm{p}>0.05$ & N/A & N/A \\
\hline Magnesium mg/l & $2.74 \pm 0.18$ & $1.80 \pm 0.06$ & $\mathrm{p}>0.05$ & $2.74 \pm 0.18$ & $1.88 \pm 0.08$ & $\mathrm{p}>0.05$ & N/A & N/A \\
\hline
\end{tabular}

Results are given as mean \pm standard deviation

FMEnv $=$ Federal Ministry of Environment Nigeria; DPR $=$ Department of Petroleum Resources

$\mathrm{N} / \mathrm{A}=$ Not Available

$\mathrm{P}>0.05=$ Significant difference $\mathrm{P}<0.05=$ No Significant difference 
Table 3: Heavy Metal Concentration in Water Samples (mean \pm standard deviation)

\begin{tabular}{|l|l|l|l|l|l|l|l|l|}
\hline Parameters & $\begin{array}{l}\text { Effluent } \\
\text { discharge }\end{array}$ & Upstream & P-VALUE & $\begin{array}{l}\text { Effluent } \\
\text { discharge }\end{array}$ & Downstream & $\begin{array}{l}\mathrm{p}-\text { value } \\
\text { DPR } \\
(\text { ref. })\end{array}$ & $\begin{array}{l}\text { FMENV } \\
(\text { ref. })\end{array}$ \\
\hline Lead $(\mathrm{Pb}) \mathrm{ppm}$ & $0.01 \pm 0.01$ & $0.01 \pm 0.00$ & $\mathrm{P}<0.05$ & $0.01 \pm 0.01$ & $0.01 \pm 0.00$ & $\mathrm{P}<0.05$ & $\mathrm{~N} / \mathrm{A}$ & $<1$ \\
\hline Zinc $(\mathrm{Zn}) \mathrm{ppm}$ & $0.56 \pm 0.47$ & $0.15 \pm 0.01$ & $\mathrm{P}<0.05$ & $0.56 \pm 0.47$ & $0.14 \pm 0.01$ & $\mathrm{P}<0.05$ & 5 & $<1$ \\
\hline Copper $(\mathrm{Cu}) \mathrm{ppm}$ & $0.74 \pm 0.06$ & $0.18 \pm 0.01$ & $\mathrm{p}>0.05$ & $0.74 \pm 0.06$ & $0.16 \pm 0.01$ & $\mathrm{p}>0.05$ & $\mathrm{~N} / \mathrm{A}$ & $<1$ \\
\hline Iron $(\mathrm{Fe}) \mathrm{ppm}$ & $4.29 \pm 0.00$ & $2.83 \pm 0.04$ & $\mathrm{p}>0.05$ & $4.29 \pm 0.00$ & $2.76 \pm 0.03$ & $\mathrm{p}>0.05$ & $\mathrm{~N} / \mathrm{A}$ & 20 \\
\hline $\begin{array}{l}\text { Chromium }(\mathrm{Cr}) \\
\text { ppm }\end{array}$ & $0.54 \pm 0.03$ & $0.01 \pm 0.00$ & $\mathrm{p}>0.05$ & $0.54 \pm 0.03$ & $0.01 \pm 0.00$ & $\mathrm{p}>0.05$ & $\mathrm{~N} / \mathrm{A}$ & $<1$ \\
\hline Arsenic $(\mathrm{As}) \mathrm{ppm}$ & $0.01 \pm 0.00$ & $0.00 \pm 0.01$ & $\mathrm{P}<0.05$ & $0.01 \pm 0.00$ & $0.00 \pm 0.01$ & $\mathrm{P}<0.05$ & $\mathrm{~N} / \mathrm{A}$ & $<1$ \\
\hline Nickel $(\mathrm{Ni}) \mathrm{ppm}$ & $0.00 \pm 0.01$ & $0.03 \pm 0.01$ & $\mathrm{P}<0.05$ & $0.00 \pm 0.01$ & $0.03 \pm 0.01$ & $\mathrm{P}<0.05$ & N/A & $<1$ \\
\hline Vanadium(v) ppm & $0.00 \pm 0.00$ & $0.00 \pm 0.00$ & $\mathrm{P}<0.05$ & $0.00 \pm 0.00$ & $0.00 \pm 0.00$ & $\mathrm{P}<0.05$ & N/A & $<1$ \\
\hline Cadmium $(\mathrm{Cd})$ & $0.00 \pm 0.00$ & $0.00 \pm 0.00$ & 05 & $0.00 \pm 0.00$ & $0.00 \pm 0.00$ & $\mathrm{P}<0.05$ & N/A & $<1$ \\
\hline
\end{tabular}

Results are given as mean \pm standard deviation

FMEnv. = Federal Ministry of Environment Nigeria; N/A = Not Available; $\mathrm{P}>0.05=$ Significant difference $\mathrm{P}<0.05=$ No Significant difference 